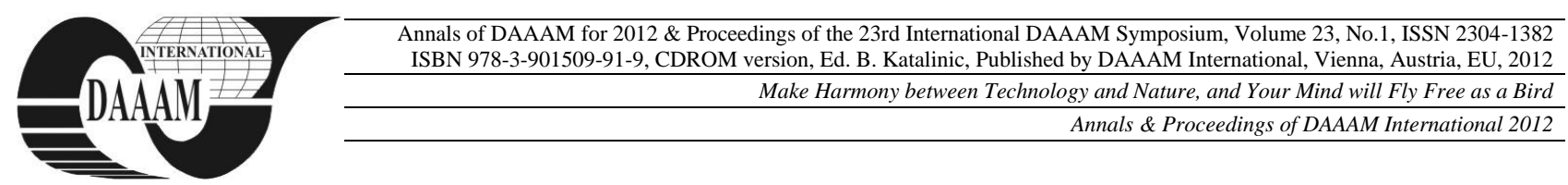

\title{
OPEN INNOVATION IN PRACTICE - CASE OF ROMANIA
}

\author{
NICOLOV, M[irela] \& DOLCA, I[oan]
}

\begin{abstract}
In the present paper we make a study on the types of innovations in the last decade in industry and services sector. After a brief review of existing innovation models in the literature, are presented different types of innovators: product innovations, process innovations and product and process innovations in industry and services sector in Romania. It is done a modeling of innovation types between 2000 and 2010 and a forecasting for the next 20 years. It's a new study based on data that were taken in Romania only after 2000.

Keywords: Innovation, Product and Process innovations, innovations in services sector, innovations in industry sector, Measurement of economic growth
\end{abstract}

\section{INTRODUCTION}

This paper presents a study on the types of innovations between 2000 and 2008 in the industry and services sector. After a brief review of existing innovation models in the literature, it is presented different types of innovations: product innovations, process innovations, respectively product and process innovations present in companies from industry and services sector in Romania. It's a new study based on data that were taken in Romania only after 2000[1]. The limitation of this model appear because there is a small number of values reported by the National Institute of Statistic from Bucharest (from www.insse.ro). In the future we want to create an econophysics model to describes the evolution of this sector (research development and innovation sector-RDI sector).

\section{LITERATURE REVIEW}

Innovation is an activity that results in a product (good or service) new or significantly improved which is introduced in their own business or is a new or significantly improved process. Innovation is based on the results of new technologies, technological development, new combinations of existing technology or knowledge obtained using other company, according to the definition of innovation in Romanian Statistical Yearbook (2010)[1].

Models of innovation are closely related to new scientific discoveries and the fundamental research, in applied research, technical applications. In practice is done by introducing scientific discoveries, like the introduction of new products, processes and services. These new innovative scientific and technical achievements, resulting from production processes are transformed into market able goods and then disposed of. Innovation process evolves starting with the 1950-1960 period from a linear model to model more complex integrated and characteristic period 1980-1990 [2]. Rothwell identified five generations of innovation models that represent stages in the evolution of economic thought and economic realities of the community of scientists [2].

Marinova and Phillimore presented in the book: "The International Handbook of Innovation" a chapter where are presented the following types of innovation models $[3 \div 13]$.

(1) First-generation black box model;

(2) A second generation - linear models (including "technology push" and "need pull");

(3) The third generation - interactive models (including models of coupling and integrated models);

(4)The fourth generation - models of innovation systems (including networks and national innovation systems);

(5) The fifth generation - and evolutionary models;

(6) The sixth generation - innovative models of type Milieu.

The scope of new product innovation is higher modes of combination which are more diverse, more complex and sophisticated. This development logic was used to explain why, in ancient times, the inhabitants of the vast area of Eurasia came to be the most innovative, sophisticated and tech population than isolated populations in other parts of the world. Might infer that large firms should be more innovative than small ones. However, modern companies are not closed, nothing compared to isolated populations in ancient times. Companies have learned, out of necessity reciprocal measures to monitor closely applied widely in search of new ideas, input, and inspiration. It can be said that it is particularly important for small businesses to offset the small interaction with the outside world and internal resources. The increasing complexity of knowledge base necessary to achieve innovation means for large firms a dependence on the external actions in their innovative activity. It is therefore necessary to cultivate knowledge absorption capacity, which is a necessity for innovative companies whether small or big companies. Such knowledge is composed of "routines" which are reproduced in practice and causes of "organizational 
memory" [9]. Over time, the organizational structure of the company and its knowledge base evolves together in an environment that is beneficial to the daily operations of the company. This concept was supported, given the necessary facilities to communicate internally and to interact with the company, which significantly boosts an existing set of existing knowledge and competence of the company called technical changes. Xerox, for example, has developed both PC and mouse, but failed to commercially exploit these innovations. Research in this area emphasizes the need for innovative companies that allow groups of people within the organization, sufficient freedom in experimenting new solutions. This allows for patterns of interaction within the firm, mobilizing its knowledge base when faced with new challenges $[8,9,10,11]$.

\subsection{Types of innovations}

Product innovation is the placing of a new good or new service or significantly improved with respect to its characteristics, such as improved software, user-friendly introduction to elements, components or subsystems. Innovation must be new for the company, but need not be new to the industry or market. It does not matter if the innovation originally appeared in respondent company or other businesses [1].

Process innovation corresponds to implementing a production process, a method of distribution or a new or significantly improved support activities. Innovation (new or improved) must be new for the company, but is no need be new to the industry or market. It does not matter if the innovation originally appeared in respondent or other business enterprise. It is excluded here purely organizational innovation, according to the definition of innovation in Romanian Statistical Yearbook from 2010 [1].

We can divide an economy in two sectors industry and services sector. Both sectors depend on innovation. A specific research area in the industry sector is open innovation, first by using computers and high-tech industry. Was neglected the research in services sector. In particular is needed more service science in financial services industry. There are researchers which are adapting open innovation concepts from industry to financial services.

The concept of open innovation used by different companies suggest that companies use internal ideas as well as external ideas and internal and external path to market. Fasnacht defined the open business models in the context of financial services industry [14]. He adapted and enhanced the basic concepts of open innovation and developed a framework for understanding industry dynamics in banking. This is a way to obtain organizational energy by using open innovation to sustain profitable growth [14].

Financial services industry follow a big transformation. Economies were triggered through a number of developments in markets and economics, demographics, customers, technology and policies during the last two decades. Fasnacht, like many managers and researchers, assumes that the shift from a closed to an open innovation paradigm is one major consequence of the trends and the recent developments. $\mathrm{He}$ argues that open innovation in this context is not a new business paradigm - it is a mindset characterized by openness, flexibility, and customer integration.

Opening up business models in the financial services is a challenge but also a chance for those that understand the importance of this strategic change [14].

\section{RESEARCH METHODOLOGY}

Research methodology is based on simulation data's on the types of innovations for the period 2000-2008. The studies presented here were performed on product innovations, process innovations and product and process innovations. Were studied different cases such as industry sector and services sector. Data were taken from the site of the Bucharest National Statistics Institute from Tempo online database accessed in September 2012 (data's updated on 21/10/2010)[15].

The central objective of this study is the observation types of innovations in Romania during 2000-2008 in the industry and in the services sector.

The main objective was to see if the real data in compliance or not a particular model, if that a particular regression.

\section{RESULTS}

The data used in this study are taken from the site of the Romanian National Statistics Institute, the database Tempo - online database updated 10/21/2010.

Typology will be presented to the innovations, the class size and economic activities. Data refer to companies from industry and services sector $[14,15]$.

\subsection{Product Innovations}

Are registered in Romania in 2002, a total of 582 companies which have product innovations only. In 2004 their number decreased to $81.1 \%$ of the value recorded in 2002. In 2006 this figure increased to $90.21 \%$, while the number of product innovations in 2008 before recovering to a value of 3.35 times higher than in 2002 and 1951 for only product innovations.

In the industry sector, product innovations represent $61.37 \%$ of all innovations registered in Romania. Number of product innovations in the industry registered in Romania decreased from 357 in 2002 to 315 in 2004 to 291 in 2006 respectively, because in 2008 the figure recorded in National Statistical Institute databases from Bucharest to be 689 , meaning a value of 3.53 times in 2002 and $64.68 \%$ of those registered in Romania.

In the service sector in Romania, product innovations represents $38.66 \%$ of the total registered in Romania as 
225. The number of product innovations decreases in Romania in 2004 to 157 , after that grows from 234 in 2006 and in 2008 was 3.06 times higher than in 2002. The 2008 value of product innovations in the services sector represents $35.32 \%$ of those registered in Romania in 2008 .

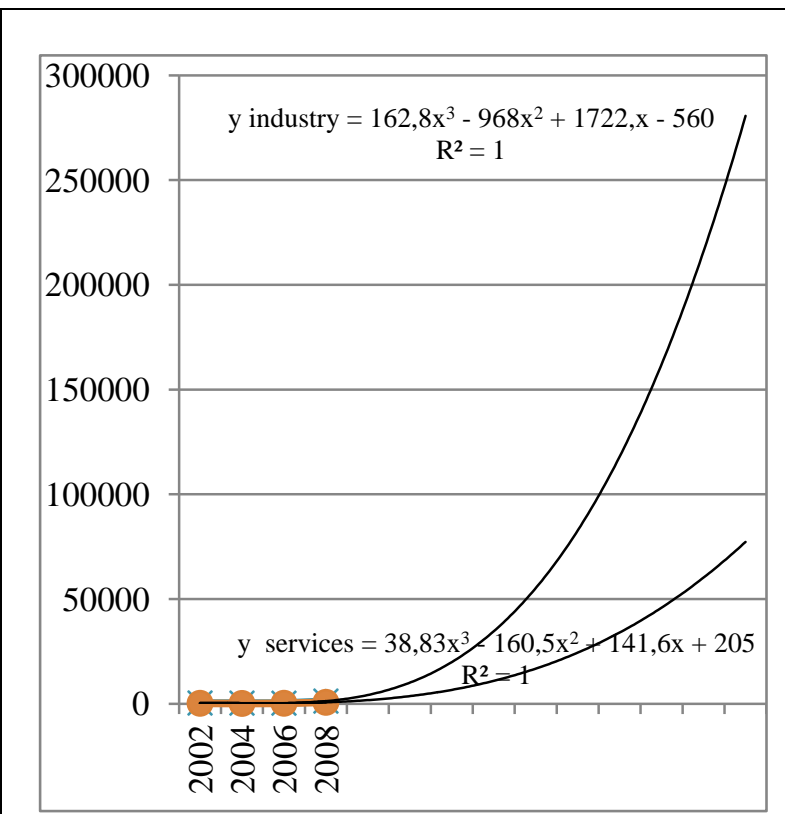

Fig. 1: Product Innovations in Romania in between 2000-2008

Forecasting for the next 20 years from 2002.

(Author's calculus based on $[15,16]$ )

\subsection{Process Innovations}

The number of process innovations in Romania registered a total increase in value from 413 in 2002 to 1203 in 2004. In 2006 it was a drop to 1169 and in 2008 their value to increase 9.87 times.

In industry sector, the number of process innovations in 2002 was $76.27 \%$ of their total recorded in that year in Romania. Their value increased by 2.47 times in 2004 respectively 2.19 times in 2006, while in 2008 this amount is 7.14 times higher than in 2002 .

In the service sector only process innovations in 2002 represents $23.73 \%$ of the total value recorded in that year in Romania. Their value increases from 98 in 2002 to 423 in 2004, to 477 in 2006 because in 2008 the number of process innovations to be 18.64 times in 2002 and represent $44.79 \%$ of those registered in Romania.

\subsection{Product and Process Innovations}

Total number of product and process innovations registered in Romania increased from 2968 in 2002 to 3461 in 2004,to the 4276 value in 2006, in 2008 their value drop to the value of 3956 . In the industry sector was recorded the highest numbers of product and process innovations in 2002 at the values of $75.1 \%$ of the total registered in Romania. Values of product and process innovations in the industry increased from value 2229 recorded in 2002 to 2369 in 2004 respectively in 2006 and reach to 2781 in 2008 .

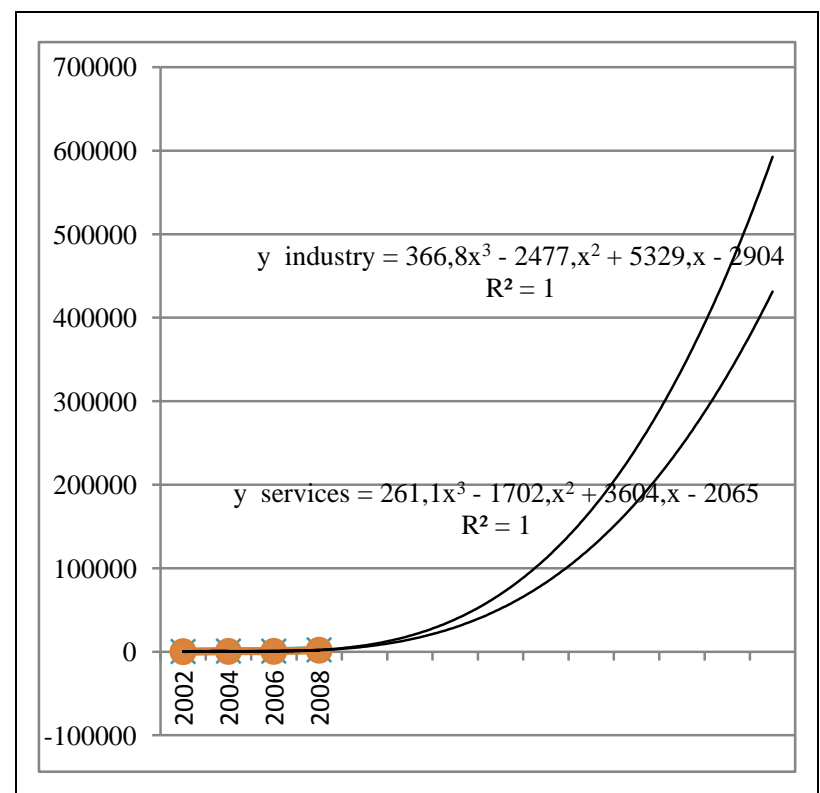

Fig. 2: Process innovations in Romania in between 2000 and 2008 Forecasting for the next 20 years from 2002.

(Authors calculus based on $[15,16]$ )

It was a growing of 1.11 times, up to a value of 2489 , representing $62.92 \%$ of the total registered that year.

In the services sector, product and process innovations is only $24.9 \%$ of those registered in 2002 in Romania. This value increases to 739 recorded in 20021092 recorded in 2004 and 1467 the value recorded in 2008. It seems that there is an increase of 1.98 times in 2008 and the value $37.08 \%$ recorded in 2008 represents the total number of product and process innovations registered in Romania in 2008.

When we make a model and forecasting of product Innovations, Process Innovations and Product and

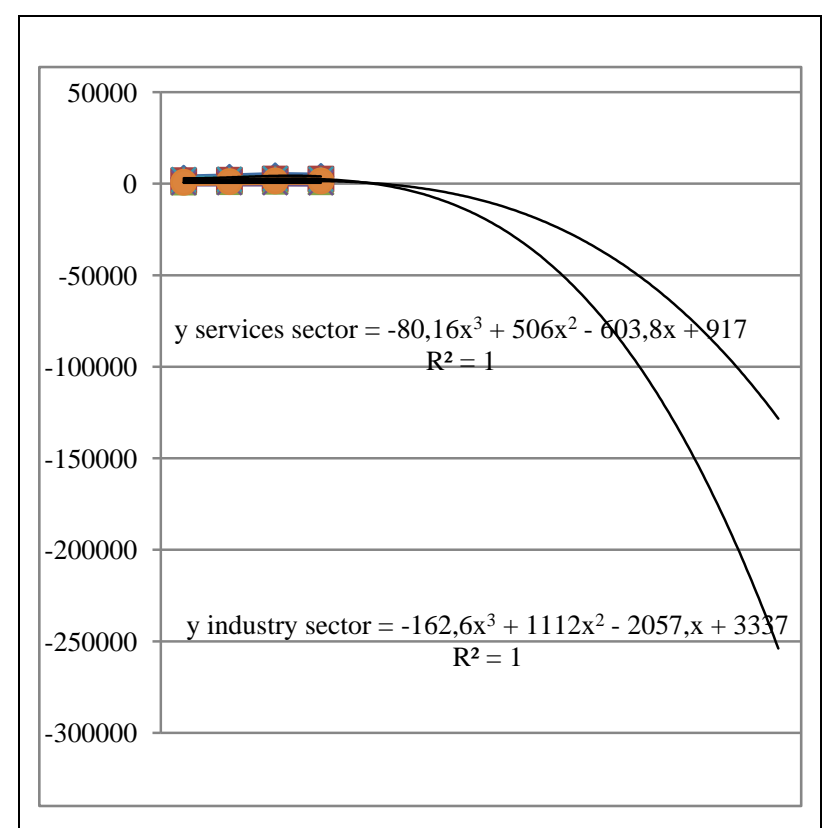

Fig. 3: Product and Process Innovations in Romania in between 2000 and 2008. Forecasting for the next 20 years from 2002.

(Authors calculus based on $[15,16]$ ) 
Process Innovations we can obtain the next regression curves of third degrees:

$$
\mathrm{Y}=\mathrm{A} \cdot \mathrm{X}^{3}+\mathrm{B} \cdot \mathrm{X}^{2}+\mathrm{C} \cdot \mathrm{X}+\mathrm{D}
$$

The values for coefficients $\mathrm{A}, \mathrm{B}$ and $\mathrm{C}$ are listed in the tables below

\begin{tabular}{|c|c|c|c|c|c|}
\hline & A & B & C & D & $\mathbf{R}^{\mathbf{2}}$ \\
\hline TOTAL & 628 & -4180 & +8934 & -4969 & 1 \\
\hline Industry sector & 366.8 & -2477 & 5329 & -2904 & 1 \\
\hline Services sector & 261.1 & -1702 & 3604 & -2065 & 1 \\
\hline
\end{tabular}

Tab. 1. Process innovations. (Authors calculus based on $[15,16]$ )

\begin{tabular}{|c|c|c|c|c|c|}
\hline & A & B & C & D & $\mathbf{R}^{\mathbf{2}}$ \\
\hline TOTAL & 201.6 & -1128 & 1863 & -355 & 1 \\
\hline Industry sector & 162.8 & -968 & 1722 & -560 & 1 \\
\hline Services sector & 38.83 & -160.5 & 141.6 & 205 & 1 \\
\hline
\end{tabular}

Tab. 2. Product innovations (Authors calculus based on $[15,16]$ )

\begin{tabular}{|c|c|c|c|c|c|}
\hline & A & B & C & D & $\mathbf{R}^{2}$ \\
\hline TOTAL & -242.8 & 1618 & -2661 & 4254 & 1 \\
\hline Industry sector & -162.6 & 1112 & -2057 & 3337 & 1 \\
\hline Services sector & -80.16 & 506 & -603.8 & 917 & 1 \\
\hline
\end{tabular}

Tab. 3. Product and process innovations. (Authors calculus based on $[15,16])$

\section{CONCLUSIONS}

In conclusion it may be noted that for all cases studied here: the general case study for Romania during 2000-2008, the case of industry and services sector, product and process innovations in all cases is higher than process innovations and product innovations. It seems that the process innovations in the industry have higher values than in services sector.

We can see from the present study that the product and process innovations from industry and services sector is a phenomenon which are in decreasing the others like product innovators only and process innovators only are increasing phenomenon for the next 20 years.

In conclusion we can say that the case of industry and services sector belongs to the sixth-generation innovation models which is the "Technology Innovation" and is based on modeling, simulation, virtual reality, extracting data from databases, artificial intelligence, rapid prototyping etc

\section{REFERENCES}

[1] ***, Statistical Yearbook of Romania(2010), Chapter 15. Enterprise activity, cap.13. Science Technology and Innovation, 2010

[2] Rothwell R. (1994), Towards the Fifth-generation Innovation Process, International Marketing Review, vol.11, No.1, pp.7-31

[3] Marinova D., Phillimore J.,(2003), Models of innovation, $\hat{\imath}$ The International Handbook of Innovation, edited by Larisa V. Shavinina, Elsevier Science Ltd., p.44-53

[4] Le Corre A., Mischke G., (2006), The Innovation Game. A New Approach to Innovation Management and R\&D, Springer US, 2006

[5] Galanakis K., Innovation process, (2006) Make sense using systems thinking, Technovation, november , p.1222-1232
[6] Dodgson, M., Gann D., Salter A.,(2008), The management of technological Innovation, Oxford University Press

[7] Gann, D. and Dodgson, M. , Innovation Technology: How New Technologies Are Changing The Way We Innovate, National Endowment for Science, Technology and the Arts, London, 2007.

[8] Tushman M.L., Anderson P.,(1986), Technological Discontinuities and Organizational Environments, Adminstrative Science Quaterly, 31(2), p.439-465.

[9] Fagerberg J., (2005), Innovation: A Guide to literature, pag.1-27, în The Oxford Handbook of Innovation, ed.by Jan Fagerberg, David C.Mowery and Richard R. Nelson, Oxford University Press, 2005.

[10] Fagerberg J.,Godinho M.,(2005), Innovation and Catching up, pag.514-542, în The Oxford Handbook of Innovation, ed.by Ian Fagerberg, David C.Mowery and Richard R. Nelson, Oxford University Press, 2005.

[11] Fagerberg Jan, Verspagen Bart, (2009), Innovation studies - The emerging structure of a new scientific field, Research Policy,no 38, p.218-233

[12] Lundvall, B.- $\AA$., (2007),National innovation systems - analytical concept and development tool, Industry and Innovation,14/1, p.95-119,

[13] Kusiak, A., (2007), Innovation science: a primer, Int.J.Computer Application in Technology, 28/2-3, p.148.

[14] Fasnacht D., (2009), Open Innovation in the Financial Services, Springer, Berlin.

[15] http://www.insse.ro/cms/files/Anuar\%20statistic/13/13\%20Stiinta ,\%20tehnologie\%20si\%20inovare_ro.pdf , Accessed on: 2012-09. 12

[16] https://statistici.insse.ro/shop/index.jsp?page=tempo3\&lang=ro\&i nd=INO101A, Accessed on: 2012-09-12 